\title{
Seasonal Variation and Inherent Variability of Trace Elements in Oysters and Their Implications for Indicator Studies
}

\author{
The Late C. R. Boyden ${ }^{1}$ and D. J. H. Phillips ${ }^{2 *}$ \\ ${ }^{1}$ Applied Geochemical Research Group, Imperial College, London, England \\ ${ }^{2}$ Fisheries Research Station, 100A Shek Pai Wan Road, Aberdeen, Hong Kong
}

\begin{abstract}
The seasonal variation in concentrations and body burdens of 8 trace elements in the Pacific oyster Crassostrea gigas Thunberg was investigated, using individuals transplanted from Menai Strait in Wales to 2 Cornish estuaries. Seven of the 8 elements exhibited generally similar profiles for concentration, maxima occurring in winter and minima in summer. Some differences were noted in profiles for body burdens of these elements, depending on the loss of metals with gametes at spawning or on the rate of element uptake during autumn and winter. However, in each case, seasonal variation in concentration of the element was defined largely by changes in the weights of the whole soft parts of oysters, which in turn were dependent on the gametogenesis-spawning cycle. The 8th element, manganese, exhibited quite different kinetics; tissue weights of the oysters were of much less importance in defining seasonality of this metal. These data are compared to those of other authors in attempts to produce general conclusions on the seasonality of trace elements in bivalve molluscs. The inherent variability of zinc levels in three populations of two species of oyster, C. gigas and Ostrea edulis ( $L$.), was also investigated to estimate the minimum number of individuals required to characterise element levels in an oyster population. The possible reasons for the existence of inherent variability of element concentrations in bivalves are discussed, and the implications of both inherent variability and seasonality of elements are considered with respect to monitoring studies using bivalves as biological indicators of metal abundance.
\end{abstract}

\section{INTRODUCTION}

Oysters, mussels and other bivalve molluscs accumulate a wide range of pollutants from water and food to levels which are relatively simple to measure. Theoretically, the study of their content of pollutants in different areas may provide a quantitative estimate of the time-integrated ambient contamination of different water masses. Phillips $(1977,1980)$, in reviews of the use of biological indicator organisms to monitor trace metals, considered bivalve molluscs as the most reliable indicators recognized to date. Their use in global monitoring studies, suggested by Goldberg (1975), now seems realistic.

However, several authors have emphasised the need for caution in monitoring studies using bivalves, as certain parameters are known to influence the amounts of trace metals accumulated by these organisms, and

\footnotetext{
- Addressee for reprint requests
}

may therefore interfere with the elucidation of true location-based differences in contamination. For example, metals may vary in both concentration and total body load in bivalves with age or size (Boyden, 1974, 1977; Bryan and Uysal, 1978). Season may also be a significant perturbant of element levels (Bryan, 1973; Frazier, 1975, 1976; Phillips, 1976 a). Other such interferences include vertical position of the bivalve on the shore-line or in the water column (Nielsen, 1974; De Wolf, 1975; Phillips, 1976 a) and sex of the animal (Watling and Watling, 1976).

Quantitatively, the most important of these variables are size or age of the bivalves and season of collection (Phillips, 1980). Previous reports by Boyden (1974, 1977) were concerned exclusively with the effects of size on element concentration in molluscs. The present paper considers the influence of season on the concentrations of 8 trace metals in two populations of the Pacific oyster Crassostrea gigas Thunberg. In addition, simple statistical methods are proposed to define the 
magnitude of residual or inherent variability in element concentrations of bivalves, present when perturbing parameters such as those noted above have been eliminated.

\section{MATERIALS AND METHODS}

\section{Seasonal Studies}

Approximately 500 hatchery-reared oysters, Crassostrea gigas Thunberg, of similar size and age were transplanted in September 1972 from Menai Strait, Anglesey, North Wales to the Helford Estuary in Cornwall, England. On the same date, a further $350 \mathrm{C}$. gigas from the same source were transplanted to the Restronguet Creek (a branch of the Fal Estuary) in Cornwall. The two recipient areas were selected for their differing degree of mineralisation; the Helford Estuary is relatively uncontaminated by metals, whereas Restronguet Creek is one of the most contaminated estuaries in England for certain elements (Bryan and Hummerstone, 1971, $1973 \mathrm{a}, \mathrm{b}, \mathrm{c}$; Thornton et al., 1975; Boyden, 1977). A random subsample of 38 individuals was taken at transplantation for determination of initial shell lengths, soft tissue dry weights, and element concentrations. The remaining oysters were placed in plastic cages and both populations were subsampled at approximately monthly intervals for 25 (Helford) or 17 (Restronguet) months subsequent to transplantation. All samples were maintained for $36 \mathrm{~h}$ after collection in clean filtered sea water from an offshore location to permit elimination of gut contents, prior to storage by freezing at $-20^{\circ} \mathrm{C}$. When required for analysis, samples were thawed and the shell lengths of 10 or more individuals were recorded. The whole soft parts were excised, freeze dried and ground to a fine powder after determination of dry weights. Analytical techniques were essentially identical to those reported previously (Boyden, 1977), involving digestion of the dry powder with 'Ultra grade' concentrated nitric acid, permitting reflux of the acid over a hot plate at $100^{\circ}-200^{\circ} \mathrm{C}$. Upon production of a clear solution, the nitric acid was driven off and the remaining salts were redissolved in $5-50 \mathrm{~cm}^{3} \mathrm{IN}-\mathrm{HCl}$ for analysis using a Model 303 Perkin-Elmer atomic absorption spectrophotometer. Mean concentrations and mean body burdens of eight trace metals (cadmium, cobalt, copper, iron, lead, manganese, nickel and zinc) were calculated for each sample at the appropriate wavelengths by reference to standard salt solutions. Blanks were run concurrently with samples to check contamination, which was negligible in all cases; standard addition methods indicated recoveries approaching $100 \%$ for each of the 8 elements studied.

\section{Variability Studies}

Concentrations of zinc were determined for 40 individuals from each of three populations of oysters; Crassostrea gigas and Ostrea edulis (L.) sampled at Menai Strait on 22 March 1974, and $O$. edulis taken from Restronguet Creek on 31 October 1974. Preparative and analytical methodologies were identical to those described for seasonal studies of $C$. gigas, except that the oysters were analysed individually rather than as a composite or bulked sample.

The first statistical treatment was designed to elucidate the minimum number of individuals required to establish a statistically acceptable difference between the concentrations of zinc found in oysters from each population. Single groups of $5,10,15,20,25,30$ and 35 individual results were selected by a random process from each set of 40 individual concentrations. Mean concentrations of zinc, their standard deviations and the corresponding coefficients of variation $(\%$, calculated as $\frac{S D}{\text { mean }} \times 100$ ) were calculated for each of these subsamples in each population. Data for each subsample category were then subjected to t-tests to indicate the probability that the subsamples were derived from populations differing in zinc concentration.

The second statistical treatment involved determination of the variability of the data in relation to sample size, and was designed to elucidate the minimum number of individuals accurately characterising the element levels found in a given population. Groups of $5,10,15,20,25,30$ and 35 individual results were randomly selected, as above, from the 40 results for each population; this was performed 5 times for each size category. Five sets of values for the mean, standard deviation and coefficient of variation were thus generated for zinc levels in each subsample size category in each population. The 5 coefficients of variation in each category were then used to indicate variability of the data by examination of the variation among the coefficients. Thus means, standard deviations and coefficients of variation were calculated using the primary 5 coefficients of variation as base data. The coefficients of variation of these original coefficients were then considered in relation to subsample size categories for each of the three populations.

\section{RESULTS}

\section{Seasonal Studies}

Figures 1 and 2 deal with Crassostrea gigas introduced to the Helford Estuary from Menai Strait in September 1972. Figure 1 presents information for mean shell lengths and dry weights and for mean 
concentrations and total body burdens of cadmium, cobalt, copper and zinc. Results for lead, iron, manganese and nickel are shown in Figure 2. Data for $C$. gigas transplanted at the same time to Restronguet Creek from Menai Strait are presented in similar fashion in Figures 3 and 4.

Shell lengths attained by each of the introduced populations of oysters were similar throughout the study period. Mean dry weights of the whole soft parts were also similar until August 1973, when spawning occurred. The Helford population lost much less weight at spawning compared to the oysters in Restronguet Creek, resulting in a difference in mean dry weights of more than 2-fold in November 1973. By February 1974, this difference was much diminished.

With respect to the profiles for trace metal concentrations, it is notable that equilibration of the transplanted oysters occurred relatively rapidly for all elements in
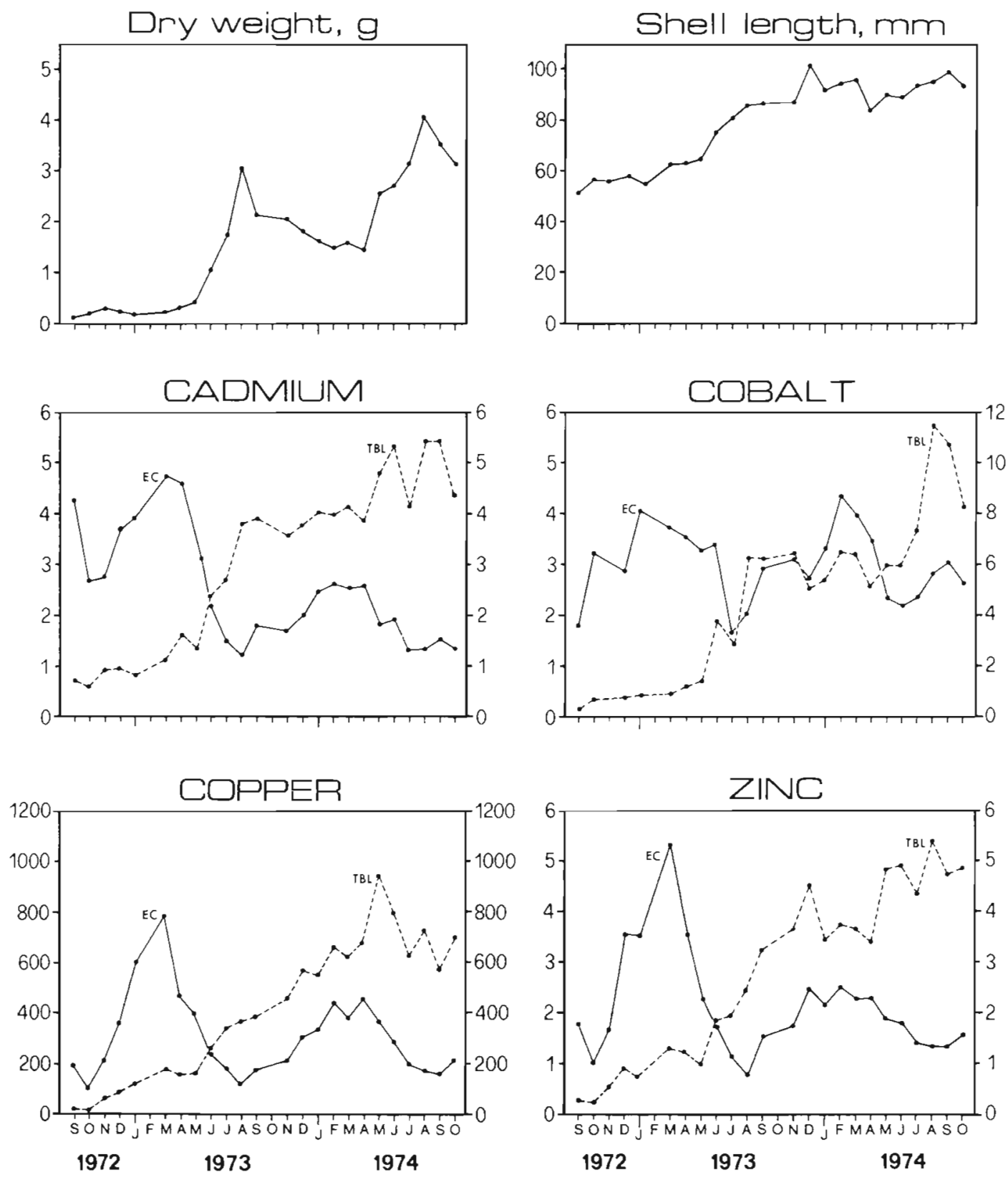

Fig. 1. Crassostrea gigas. Seasonal profiles of mean dry weights of whole soft parts and of shell lengths of oysters transplanted to Helford Estuary, Cornwall, in September 1972. Seasonal profiles for cadmium, cobalt, copper and zinc shown in terms of both element concentration ( $\mathrm{EC}_{i}$ continuous lines, left-hand axes) and total body loads of elements (TBL; dashed lines, right-hand axes). Data for metals expressed as $\mu \mathrm{g} \mathrm{g}^{-1}$ dry weight and $\mu \mathrm{g}$ total (cadmium, cobalt, copper) or $\mathrm{mg} \mathrm{g}^{-1} \mathrm{dry}$ weight and mg total 

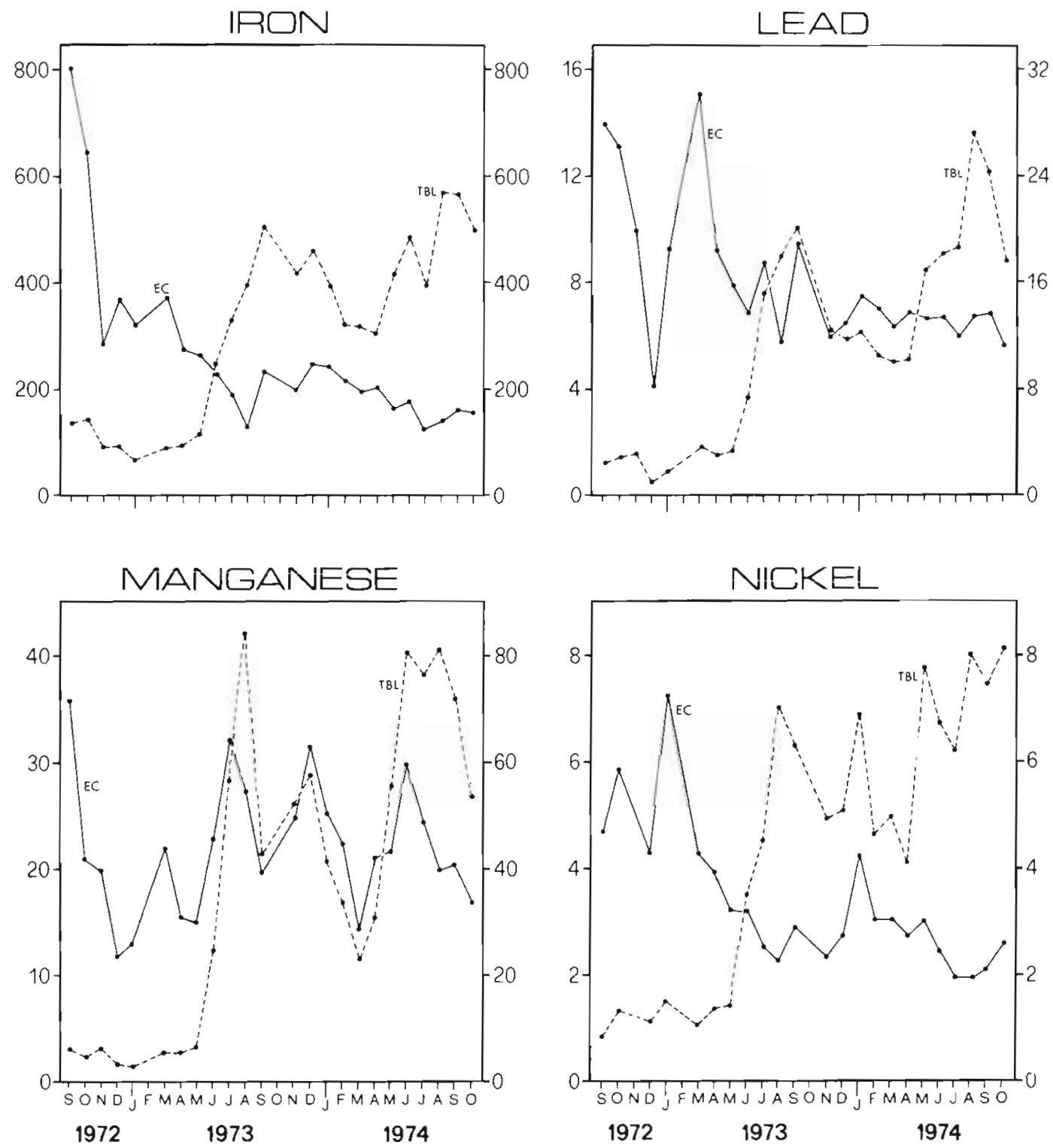

Fig. 2. Crassostrea gigas. Seasonal profiles for iron, lead, manganese and nickel in whole soft parts of oysters transplanted to Helford Estuary in September 1972. Continuous lines referring to left-hand axes show element concentrations (EC; $\mu \mathrm{g} \mathrm{g}^{-1} \mathrm{dry}$ weight): dashed lines referring to right-hand axes show total body loads of elements (TBL; $\mu$ )

both locations. Some metals (e.g. iron and lead) decreased in concentration initially, suggesting lower available levels of these elements in the new locations compared to Menai Strait. Other metals (e. g. cobalt, copper and zinc) increased in concentration subsequent to transplantation, suggesting greater availability in the new locations in these instances. However, in all cases, concentrations of elements reached a minimum or maximum within about 4 months from the date of transplantation, suggesting that by this time equilibration to the new ambient metal levels had been achieved. After the initial 4-month period, therefore, profiles are considered to be indicative of true seasonal variation in metal levels at the new locations.
Data from other authors, whilst variable, tend to support such a concept (see review by Phillips, 1980).

Because of the differences in mineralisation of the two recipient areas, differences in the degree of element accumulation by oysters also occurred. In August 1973 (when tissue dry weights of oysters in each location were similar prior to spawning), both concentrations and total body loads of cadmium in Restronguet oysters exceeded those in Helford oysters by more than 3 -fold. Comparative differences for copper and zinc were about 16-fold and 6-fold respectively, whilst those for other metals approximated only 1.6 -fold (iron, lead and manganese) or 0.8 -fold (cobalt and nickel).

Despite these differences in the relative degree of 
metal accumulation at the two locations, seasonal profiles of concentration were generally similar for a given element in oysters from both sites. This similarity lends weight to the concept that equilibrium condi-
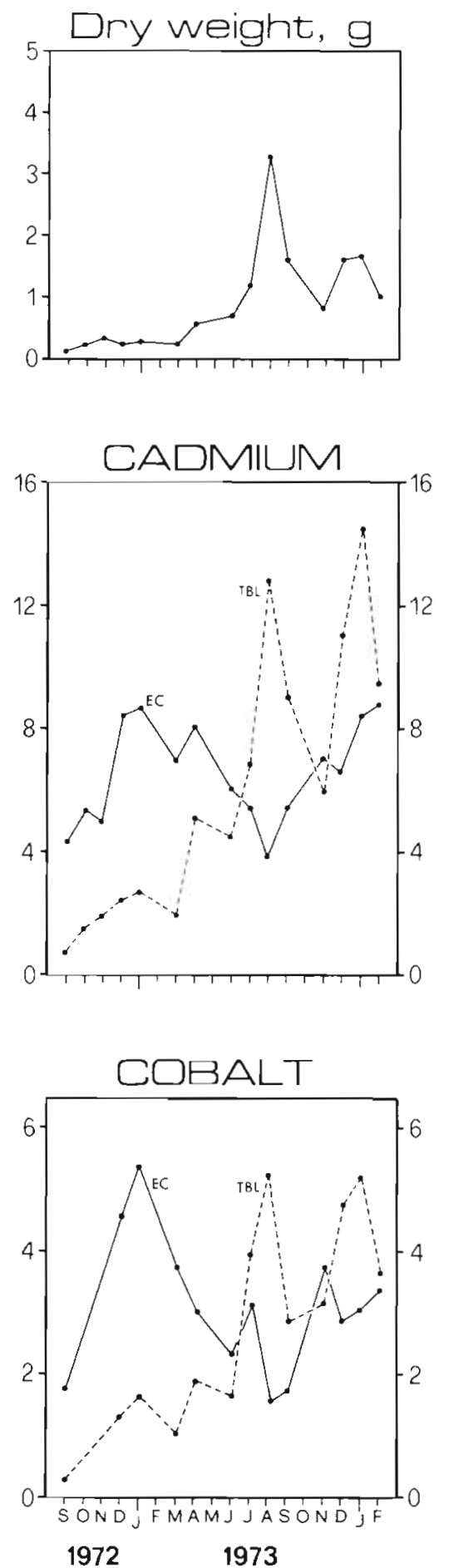

Fig. 3. Crassostrea gigas. Seasonal profiles of mean dry weights of whole soft parts and of shell length for oysters transplanted to Restronguet Creek in September 1972, and seasonal profiles of trace elements in these oysters. Data for metals shown as concentrations (EC; continuous lines, left-hand axes) and total body loads (TBL; dashed lines, right-hand axes); units are $\mu \mathrm{g} \mathrm{g}^{-1}$ dry weight and $\mu$ g total (cadmium, cobalt, copper) or $\mathrm{mg} \mathrm{g}^{-1}$ dry weight and $\mathrm{mg}$ total (zinc)

tions were attained by the oysters within a few months of transplantation. Concentrations of cadmium, cobalt, copper and zinc were greatest in January to April and least in July to September in all cases (Figs 1 and 3).
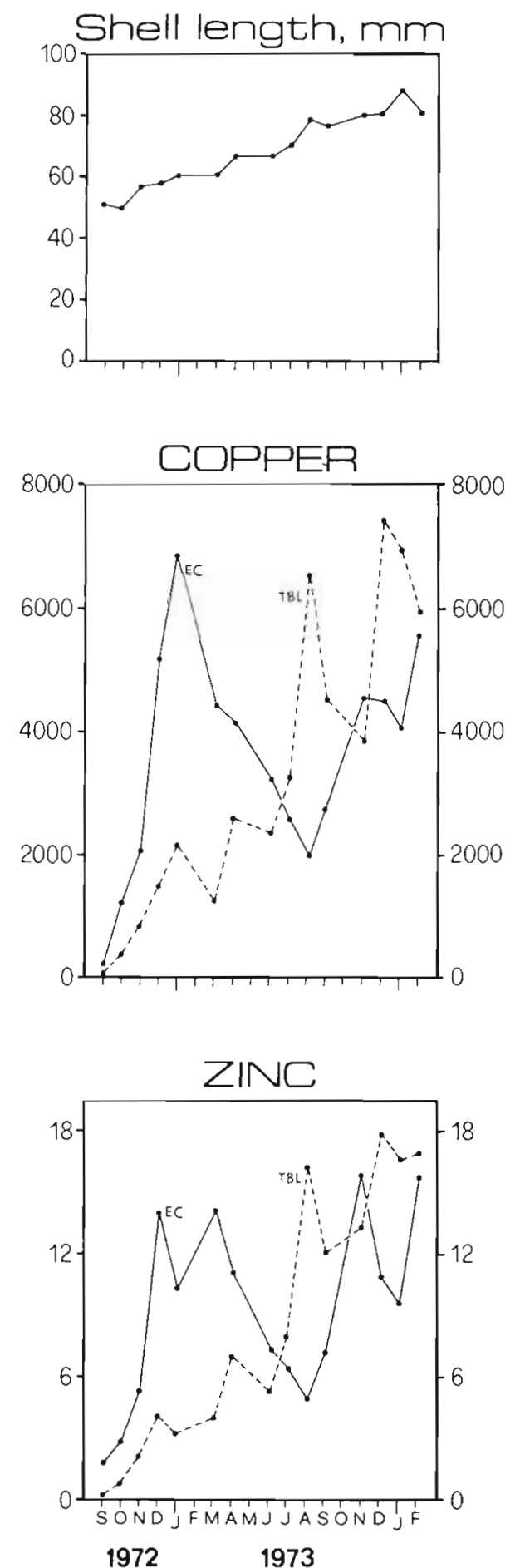
Mean body burdens of these elements increased gradually throughout the study period for the Helford population; there was no evidence of significant metal loss at spawning in August-September 1973 and little change at the same period in 1974. The oysters from Restronguet Creek, however, lost a certain amount of the total body burden of each of these elements between August and September 1973, although the concentrations of each element increased in these oysters during this period.

Seasonality of lead and nickel concentrations in the two studied populations showed some features similar to those described above. The general trend of maxima in late winter and minima in summer was again observed. However, total body burdens of these elements were rather more erratic, and the period of spawning subsequent to August was associated with losses of both metals in each population, although the losses were considerably greater in the Restronguet Creek oysters. Concentrations of iron fluctuated markedly with time, particularly in the Restronguet population, although seasonal minima in July or August were noted in all cases. However, body burdens of iron were not greatly affected by spawning. Manganese
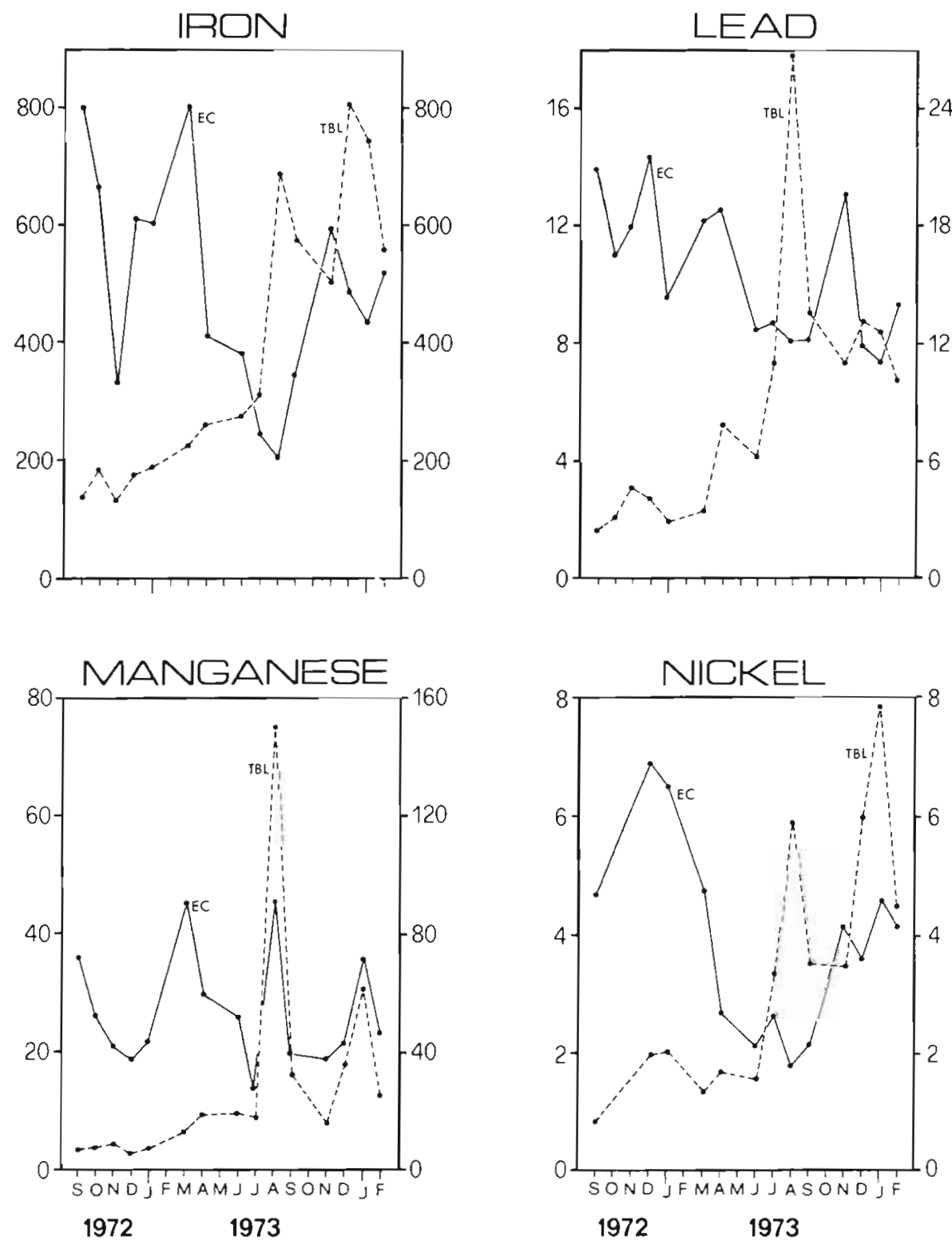

Fig. 4. Crassostrea gigas. Seasonal profiles for iron, lead, manganese and nickel in whole soft parts of oysters transplanted to Restronguet Creek in September 1972. Continuous lines referring to left-hand axes show element concentrations (EC; $\mu \mathrm{g} g^{-1} \mathrm{dry}$ weight); dashed lines referring to right-hand axes show total body loads of elements (TBL; $\mu \mathrm{g})$ 
Table 1. Crassostrea gigas and Ostrea edulis. Effect of sample size on statistical comparisons between zinc concentrations ( $\mu$ g $\mathrm{g}^{-1}$ dry weight) in random subsamples of three oyster populations

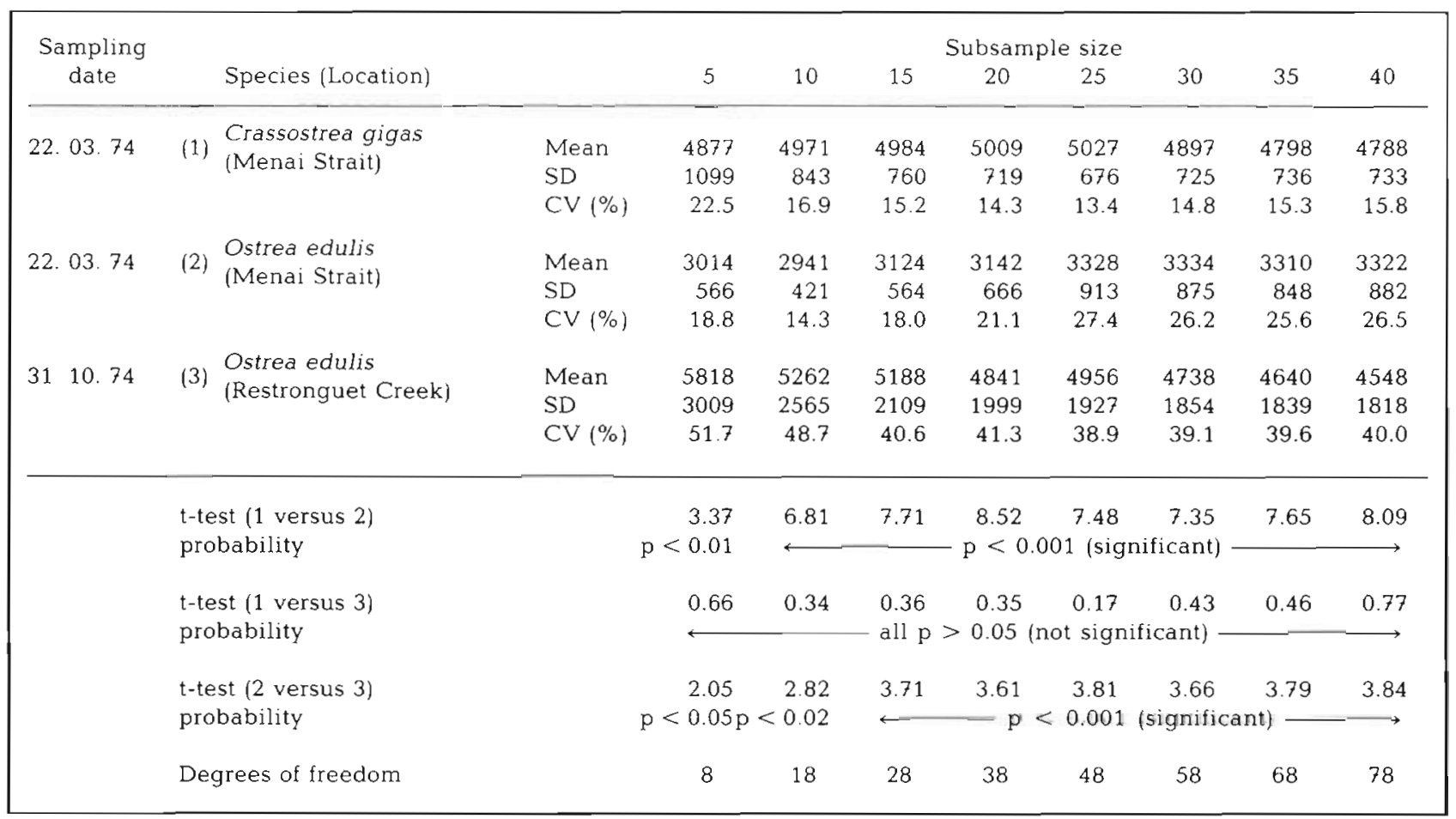

levels were the most variable, concentrations exhibiting multiple annual maxima and minima at both locations. Body burdens of this element were influenced by spawning, decreasing consistently in Helford oysters and dramatically in the Restronguet population.

\section{Variability Studies}

Data concerning the minimum sample size required to establish a statistically acceptable difference between the zinc concentrations found in different populations of oysters are shown in Table 1. It is evident that no separation of zinc levels in Populations 1 and 3 could be achieved with the numbers of individuals used in this study. The inherent variability of the data thus frustrated attempts to identify differences in the concentrations of zinc found in the two populations. By contrast, Populations 1 and 2 could be separated significantly even by using only 5 individuals from each location, and the same was true for Populations 2 and 3. The lack of improvement in the statistical assessment as sample sizes increase above 15 suggests that the use of 15 individuals from each population is sufficient to permit effective comparison of the concentrations of zinc present in these two instances. Use of the non-parametric Mann-Whitney test in comparing data for each population did not improve separation, sug- gesting that the assumption of normality inherent in the use of the t-test was justified in this case.

Results for the studies of within-sample variability are given in Table 2 , as estimates of the variation in the coefficients of variation generated for each subsample size category. It is clear that some residual variation is always encountered, regardless of the sample size taken. As the sample size becomes smaller, however, variability suddenly increases at a given point characteristic of each population. For Ostrea edulis from Menai Strait the increase occurs between subsample sizes of 15 and 10; for $O$. edulis from Restronguet

Table 2. Crassostrea gigas and Ostrea edulis. Variation in concentrations of zinc ( $\mu \mathrm{g} \mathrm{g}^{-1}$ dry weight) in oysters, expressed in terms of variability in coefficients of variation and related to sample size. See text for explanation of statistical method

\begin{tabular}{|lccccccc|}
\hline & \multicolumn{8}{c|}{ Subsample size } & \\
Species (Location) & 5 & 10 & 15 & 20 & 25 & 30 & 35 \\
\hline $\begin{array}{l}\text { Crassostrea gigas } \\
\text { (Menai Strait) }\end{array}$ & 31.7 & 29.5 & 16.0 & 18.0 & 8.8 & 9.0 & 8.3 \\
$\begin{array}{l}\text { Ostrea edulis } \\
\text { (Menai Strait) }\end{array}$ & 49.2 & 27.9 & 11.9 & 12.9 & 9.2 & 10.4 & 13.6 \\
$\begin{array}{l}\text { Ostrea edulis } \\
\text { (Restronguet Creek) }\end{array}$ & 49.3 & 30.4 & 24.1 & 18.6 & 20.3 & 19.5 & 18.7 \\
\hline
\end{tabular}


Creek the increase is between subsample sizes of 20 and 15: for Crassostrea gigas from Menai Strait the change occurs between 25 and 20 individuals per subsample. It may be concluded that the minimum number of individuals needed to accurately characterise the zinc concentrations present in these populations is 15 ( $O$. edulis, Menai Strait), 20 (O. edulis, Restronguet Creek), or 25 (C. gigas, Menai Strait).

\section{DISCUSSION}

\section{Seasonal Studies}

The two locations receiving transplanted oysters in the present study were selected because of their differing degree of mineralisation. Although the Helford catchment has moderate copper and zinc mineralisation (Thornton et al., 1975), the estuarine waters are considered to be relatively little contaminated by trace metals. By contrast, Restronguet Creek has received considerable attention because of its extreme contamination by cadmium, copper and zinc in particular, derived from past and present mining activities. Estimates of the comparative contamination of each estuary may be produced by considering data for trace metal levels in sediments; Bryan and Hummerstone $(1973 \mathrm{~b}, \mathrm{c})$ found differences between the estuaries of about 2 -fold for cadmium and manganese and about 5fold for zinc. Whilst such estimates obviously depend on the exact area of sampling within each estuary, they are nevertheless indicative of a tendency to greater mineralisation of the Restronguet Creek catchment compared to the Helford Estuary. Crassostrea gigas would be expected to respond to this difference by the uptake of differing amounts of elements from water and sediments in the two locations (Ayling, 1974; Boyden and Romeril, 1974; Phillips, 1977), and comparison of Figures 1-4 shows this to be the case.

Most data published to date on seasonality of trace metals in bivalve molluscs concern species other than Crassostrea gigas. Bryan (1973) studied the scallops Pecten maximus and Chlamys opercularis, and suggested that element seasonality might be related to temporal changes in the trace metal concentrations present in phytoplankton. Fowler and Oregioni (1976) and Phillips (1976a), studying Mytilus galloprovincialis and $M$. edulis respectively, concluded that temporal variations in element concentrations were mainly caused by changes in tissue weights of the mussels according to the sexual cycle. Thus alterations in the concentrations of at least some metals reciprocated those of whole tissue weights; body burdens of elements therefore altered little throughout the year. This explanation has received support in more recent work on $M$. edulis (Simpson, 1979), and was also consi dered of some import with respect to element seasonality in the oyster C. virginica (Frazier, 1975, 1976; cf. Galtsoff, 1964).

Figures 1-4 provide some evidence for the hypothesis that element concentrations in Crassostrea gigas in the present study are also related to the mean tissue weight of the oyster. Thus total body burdens of cadmium, cobalt, copper and zinc in oysters from the Helford Estuary (Fig. 1) increased quite smoothly throughout the study period. Fluctuations in the concentrations of each of these elements were therefore determined mainly by alterations in the mean tissue weights of the oysters, which in turn were governed by the sexual cycle. Thus as gametogenesis proceeded in spring and summer 1973, mean tissue weights of the oysters increased markedly; although total body burdens of the metals were also increasing, the weight change was more rapid and metal concentrations therefore decreased to reach a minirnum in August when tissue weights were at their maximum. In the period August 1973 to early 1974, dry weights of the oysters decreased because of spawning (August-September) and subsequent utilisation of stored glycogen. During this time, body burdens of metals were still increasing gradually and element concentrations also increased, partly as a result of the weight changes. After April 1974 the period of gametogenesis, associated with increased tissue weights and decreased element concentrations, began anew and the pattern of the previous year was repeated.

Figure 3 reveals that seasonality of these four elements in the Restronguet Creek oysters was slightly more complex. The profiles were similar to those shown in Figure 1, in terms of both element concentrations and total body burdens (despite large differences in absolute element uptake) until August 1973 when minimum concentrations and maximum tissue weights were recorded. At this time, a very great loss in weight associated with gamete loss at spawning ensued, and concentrations of each element increased markedly despite significant decreases in their respective body burdens. After November 1973, however, dry weights recovered somewhat and concentrations therefore fell transiently before gradually increasing towards the end of the study period. The essential differences between these profiles and those of the Helford oysters were the larger transient weight loss at spawning of Restronguet oysters, and the concomitant loss of a certain proportion of the total body burden of each element. Notwithstanding these differences, it is clear that concentrations of all 4 elements were mainly determined by oyster condition, and seasonal fluctuations in metal concentrations depended to a large extent on the magnitude and direction of temporal 
alterations in the dry weights of whole soft parts of the oysters.

Seasonal profiles for the concentrations and body burdens of iron, lead, manganese and nickel in the oysters studied differed somewhat from those discussed above. Although profiles of concentration for iron, lead and nickel in each population of oysters exhibited similar timing of maxima (late winter) and minima (summer) to those metals considered previously, profiles of body burdens were different. In the Helford population, body burdens of all 3 elements decreased from August to April, in contrast to the general increases seen for burdens of cadmium, cobalt, copper and zinc (compare Figs 1 and 2). In the Restronguet oysters, body burdens of lead also decreased during August to February, whilst burdens of iron and nickel decreased at spawning and exhibited a second peak in December or January. The precise reasons for this lengthy decrease in total body loads of elements are not clear. Probably the primary loss of metals noted in August to September can be ascribed to element loss with the gametes at spawning. Later events cannot be considered to be due to spawning, however. It is possible that increases in total body burdens of these elements do not occur over the winter period because the uptake processes involved are temperature dependent. Alternatively, changes in the availability of metals in the ambient waters may occur as run-off rates increase during winter. Whatever the explanation, it is clear that tissue weights were not the sole parameter influencing element concentration over this period.

Levels of manganese in oysters from both study locations were more variable than were those of any other element. Body burdens of manganese exhibited a large peak in August in oysters from both locations, followed by extreme loss of the element at spawning, particularly in the Restronguet samples. Profiles for the concentration of manganese were suggestive of two or possibly even three annual maxima and minima, and did not resemble those of any other element. Frazier $(1975,1976)$ has found that manganese in the soft parts of Crassostrea virginica exhibits very high turnover during the period of shell growth, as large amounts of this element are incorporated into the shell. During maximal shell growth, Frazier showed that the amount of manganese incorporated into the shell in one day was twice the total manganese burden of the whole soft parts. Clearly, this involvement in shell deposition must have an over-riding influence on the seasonality of manganese in $C$. virginica. It would appear likely from the present studies that this element is also involved in such processes in $C$. gigas; the data are also suggestive of significant losses of manganese in gametes at spawning. Certainly, seasonal changes in the concentration and body burden of manganese in oysters depend primarily on factors other than the cyclic changes of tissue weights associated with gametogenesis and spawning.

Comparison of these data with other such studies is instructive in some respects. The general importance of tissue-weight changes in defining element seasonality has been recognized in Mytilus edulis (Phillips, 1976a; Simpson, 1979) and $M$. galloprovincialis (Fowler and Oregioni, 1976). Maximum metal concentrations were generally coincident with minimum tissue weights of individuals in these studies, and elements were thus least concentrated in heavy prespawning mussels. This is powerful evidence for a causative link between the two parameters, as these study populations differed markedly in the timing of spawning, and also differ from oysters in this respect. In addition, it is known that some bivalve populations exhibit extended or multiple spawning in any one year; in these, element concentrations vary less dramatically, as the weight changes tend to be more gradual (see data for $M$. californianus in Goldberg et al., 1978).

The studies of Galtsoff (1964) and Frazier (1975, 1976) on element seasonality in Crassostrea virginica reveal some interesting differences from the present results. These authors found two annual minima in soft tissue weights of individuals, occurring in April (owing to depletion of glycogen stores in winter) and August (subsequent to spawning). As a result, concentrations of cadmium, copper and zinc exhibited twin peaks during the year, at the same periods. The present data for $C$. gigas differ from this profile because of the lack of a substantial increase in tissue weights in the autumn, ascribed to glycogen storage in $C$. virginica. Thus in C. gigas, tissue weight profiles are dominated by the gametogenesis-spawning cycle, and a single annual maximum in element concentration is more commonly observed.

Data for element seasonality in other populations of Crassostrea gigas are extremely sparse. Although Pringle et al. (1968) noted temporal fluctuation in the concentrations of several elements in C. gigas from the Washington coast, individual samples were collected over successive periods of 3 to 6 months and accurate seasonal profiles cannot therefore be identified on the basis of these data. The only other study known is that of Harrison (1979), whose results are reproduced here as Figure 5. It is clear that the profiles of concentrations of cobalt, iron and zinc in oysters from the Humboldt Estuary are similar to those reported in the present study, maximum concentrations occurring in February and minimum levels in August. Unfortunately, no information concerning tissue weights was quoted for these samples, and body burdens cannot therefore be calculated. The profile for manganese in the Humboldt 


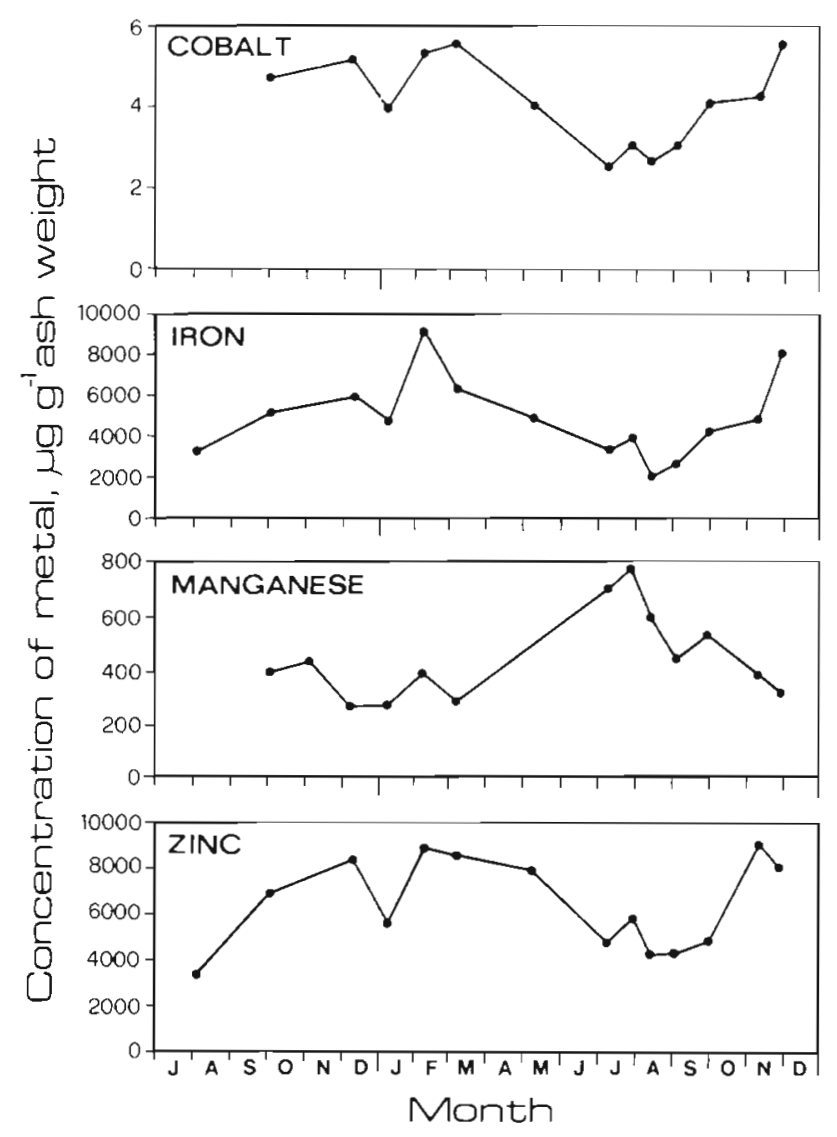

Fig. 5. Crassostrea gigas. Seasonal profiles for cobalt, iron, manganese and zinc in whole soft parts of oysters from Humboldt Estuary, July 1972 to December 1973. After Harrison (1979), reproduced by permission of the author

oysters differs substantially from those noted here; by extension of the conclusions of Frazier $(1975,1976)$, this may be caused by differences in the timing of shell growth periods in the two locations.

Investigations of element seasonality in bivalve molluscs are important in terms of their implications for the use of these organisms as biological indicators of metal abundance (Phillips, 1977, 1980). The present study suggests that element concentrations may commonly vary in Crassostrea gigas by factors of four or more during the annual cycle. Clearly, such variation is a potential disruptive factor in the use of $C$. gigas to monitor trace metal abundance at different locations. The simultaneous sampling of oysters at all sites in such an indicator survey might be considered sufficient to overcome this source of variation, but even in this case there can be no guarantee that oysters from each location are of similar condition, as the timing of spawning in bivalve populations is commonly dependent on location (e.g. Galtsoff, 1964; Seed, 1976). The best method for diminishing the effects of seasonality is therefore to time sampling programmes to occur during a period of relatively little change in element concentrations. Figures 1-4 suggest that the most likely period for such study would be in JanuaryMarch in the case of the populations studied here. Whether this would also be applicable to other populations depends essentially on the seasonal cycle of tissue weights; it is suggested that a prior knowledge of the period of least weight change in populations of oysters would be useful in decisions concerning the correct timing of sampling of such populations for monitoring purposes.

\section{Variability Studies}

The major parameters producing intrapopulation variability in trace element concentrations in bivalves are size or age of the animals and seasonal effects (differences in condition of individuals). Variables of less importance quantitatively include sex of the individuals selected and their vertical position in the water column or on the shore (Phillips, 1980). However, even if the effects of these four parameters are eliminated by the use of specific sampling procedures (Phillips, 1976a), element concentrations will still differ between different individuals. The residual variation may be termed inherent variability and is possibly a result of genetic differences between individuals, leading to variation in metabolic rates and other such parameters.

Previous publications addressing the problem of inherent variability in the element concentrations of bivalves are limited to the report of Gordon et al. (1980), concerning the mussel Mytilus californianus. These studies, involving two populations of mussels each sampled on two occasions, revealed that intrapopulation variability differs in its extent both between elements in any one population and for any one element in different populations. However, it is not completely clear from the paper of Gordon et al. as to which variability components were included in their studies. Certainly the effects of season were mainly eliminated at sampling (and are in any event minor in this species - see Goldberg et al., 1978); also, by removal of the gonad prior to analysis, most or all of the sex-based variability component was eliminated. Nevertheless, the reported sampling procedure is not specific as to the size of the mussels collected, nor with respect to their position on the shore-line. In addition, the samples were not subjected to depuration; thus a certain amount of variability (especially for metals such as aluminium and iron) would be expected due to differences between the particulate contents of different individuals. Whilst the design of the present study of element variability in bivalves differs from that of Gordon et al, the aims are essentially similar, and the 
two studies are of a complimentary rather than duplicative nature.

The existence of inherent variability in bivalve populations with respect to their accumulation of trace elements has certain important ramifications in terms of the use of bivalves to monitor metal abundance. It is clear that in some instances the element concentrations present in two populations of a species may not be separated statistically because of the existence of inherent variability (Populations 1 and 3 in Table 1 ). Even in populations that differ quite significantly in their accumulation of elements, a minimum number of individuals must be analysed from each population before separation of the data becomes statistically acceptable. The size of the minimum sample will obviously depend on the proximity of the metal levels in the studied populations, as well as on the magnitude of the inherent variability of element levels in each of the populations.

The second statistical treatment used in the present paper affords a possibility to quantify the effects of inherent variability within populations of bivalves. It is notable here that zinc concentrations in both oyster species used are known to be independent of size (Boyden, 1977). In addition, both species spawn in August in the populations studied; hence the effects of differences in condition of individuals are minimal, as sampling occurred at periods when the seasonal fluctuation in zinc concentrations was small. The influence of vertical position in the water column is also minimal in these samples, as this parameter was eliminated during collection of the bivalves studied. However, the individuals sampled were not sexed; thus any inherent variability estimated here includes the possible influence of sex-based differences, if such exist in these two species.

It may be seen from Table 2 that the minimum number of individuals needed to characterise the zinc concentrations present varies for each example given. Part of this variation is species-based; thus zinc levels in Crassostrea gigas are clearly more variable between individuals than are those in Ostrea edulis. In addition, the degree of contamination of the population studied is involved. Concentrations of zinc in $O$. edulis vary more between individuals from Restronguet Creek than for the Menai Strait population. This correlates with the higher mean level of zinc present in the former population. Many authors have previously reported that the variance of metal concentrations in biota increases faster than the mean concentration increases, although the precise reasons for this phenomenon are unclear. Lastly, it may be noted that the inherent variability of concentrations of metals in any one species differs with the metal concerned. For example, coefficients of variation for cadmium in
Mytilus edulis are generally much lower than those for zinc (Phillips, 1976b). It is clear, therefore, that inherent variability of elements in a bivalve population depends on the particular species-metal pair considered, and also on the degree of contamination involved. For this reason, the results quoted here cannot be used as a guide for other authors as to the minimum number of individuals required to characterise element levels in a bivalve population. Nevertheless, the simple statistical method used here could be employed in other studies where authors wish to ascertain the correct sample size for monitoring investigations. The method may be extended to any pollutant in any species. However, it must be emphasised that such methods in no way eliminate the need for authors to employ strictly controlled sampling techniques designed to minimise the effects of major perturbants such as animal size or seasonal condition on the results of monitoring surveys.

Acknowledgements. The data presented here were collected by CRB during his studies at Imperial College, financed by a NERC grant to Professor J. S. Webb and Dr. I. Thornton. Technical assistance from Mr. C. Monk and Mr. P. Sibley was invaluable. I wish to thank Dr Pat Boyden for her help in making these data available so that they might be published, and for her critical appraisal of the manuscript.

\section{LITERATURE CITED}

Ayling, G. M. (1974). Uptake of cadmium, zinc, copper, lead and chromium in the Pacific oyster, Crassostrea gigas, grown in the Tamar River, Tasmania. Water Res. 8: 729-738

Boyden, C. R. (1974). Trace element content and body size in molluscs. Nature, Lond. 251: 311-314

Boyden, C. R. (1977). Effect of size upon metal content of shellfish. J. mar. biol. Ass. U.K. 57: 675-714

Boyden, C. R., Romeril, M. G. (1974). A trace metal problem in pond oyster culture. Mar. Pollut. Bull 5 (5): 74-78

Bryan, G. W. (1973). The occurrence and seasonal variation of trace metals in the scallops Pecten maximus (L.) and Chlamys opercularis (L.). J. mar biol. Ass. U.K. 53: 145-166

Bryan, G. W., Hummerstone, L. G. (1971). Adaptation of the polychaete Nereis diversicolor to estuarine sediments containing high concentrations of heavy metals. I. General observations and adaptation to copper. J. mar. biol. Ass. U.K. $51: 845-863$

Bryan, G. W., Hummerstone, L. G. (1973 a). Brown seaweed as an indicator of heavy metals in estuaries in south-west England. J. mar. biol. Ass. U. K. 53: 705-720

Bryan, G. W., Hummerstone, L. G. (1973 b). Adaptation of the polychaete Nereis diversicolor to estuarine sediments containing high concentrations of zinc and cadmium. J. mar. Biol. Ass. U. K 53: 839-857

Bryan, G. W. Hummerstone, L. G. (1973c). Adaptation of the polychaete Nereis diversicolor to manganese in estuarine sediments. J. mar. biol. Ass. U. K. 53: 859-872

Bryan, G. W., Uysal, H. (1978). Heavy metals in the burrowing bivalve Scrobicularia plana from the Tamar Estuary in 
relation to environmental levels. J. mar biol. Ass. U. K. 58: 89-108

De Wolf, P. (1975). Mercury content of mussels from West European coasts. Mar Pollut. Bull. 6 (4): 61-63

Fowler, S., Oregioni, B. (1976). Trace metals in mussels from the N.W Mediterranean. Mar. Pollut. Bull. 7 (2): 26-29

Frazier, J. M. (1975). The dynamics of metals in the American oyster, Crassostrea virginica. I. Seasonal effects Chesapeake Sci. 16: 162-171

Frazier, J. M. (1976). The dynamics of metals in the American oyster, Crassostrea virginica. II. Environmental effects Chesapeake Sci. 17: 188-197

Galtsoff, P. S. (1964). The American oyster Crassostrea virginica Gmelin. Fish. Bull. Fish Wildl. Serv. U.S. 64: 1-480

Goldberg, E. D. (1975). The mussel watch - a first step in global marine monitoring. Mar. Pollut. Bull 6 (7): 111

Goldberg, E. D., Bowen, V. T., Farrington, J. W., Harvey, G., Martin, J. H., Parker, P. L., Risebrough, R. W., Robertson, W., Schneider, E., Gamble, E. (1978). The mussel watch. Envir. Conserv. 5: 101-125

Gordon, M., Knauer, G. A., Martin, J. H. (1980). Mytilus californianus as a bioindicator of trace metal pollution: Variability and statistical considerations. Mar. Pollut Bull. 11 (7): 195-198

Harrison, F. L (1979). Effect of the physicochemical form of trace metals on their accumulation by bivalve molluscs In: Jenne, A. (ed.) Chemical modeling in aqueous systems Am. Chem. Soc. Symp. Series, No. 93, pp. 611-634

Nielsen, S. A. (1974). Vertical concentration gradients of heavy metals in cultured mussels. N.Z. Jl mar. Freshwat. Res. 8: 631-636
Phillips, D. J. H (1976a). The common mussel Mytilus edulis as an indicator of pollution by zinc, cadmium, lead and copper I. Effects of environmental variables on uptake of metals. Mar. Biol. 38: 59-69

Phillips, D. J. H. (1976b). The common mussel Mytilus edulis as an indicator of pollution by zinc, cadmium, lead and copper. II. Relationship of metals in the mussel to those discharged by industry. Mar. Biol 38: 71-80

Phillips, D. J. H. (1977). The use of biological indicator organisms to monitor trace metal pollution in marine and estuarine environments - a review. Envir. Pollut. 13: 281-317

Phillips, D. J. H. (1980). Quantitative aquatic biological indicators: Their use to monitor trace metal and organochlorine pollution, Applied Science Publishers, London.

Pringle, B. H., Hissong, D. E., Katz, E. L., Mulawka, S. T (1968). Trace metal accumulation by estuarine mollusks. J. sanit. Engng Div. Am. Soc. civ. Engrs 94: 455-475

Seed, R. (1976). Ecology. In: B. L. Bayne (ed.) Marine mussels: Their ecology and physiology, Cambridge University Press, Cambridge, pp. 13-65

Simpson, R. D. (1979). Uptake and loss of zinc and lead by mussels (Mytilus edulis) and relationships with body weight and reproductive cycle. Mar. Pollut. Bull. 10 (3): $74-78$

Thornton, I., Watling, H., Darracott, A. (1975). Geochemical studies in several rivers and estuaries used for oyster rearing. Sci. Total Environ. 4: 325-345

Watling, H. R., Watling, R. J. (1976). Trace metals in Choromytilus meridionalis. Mar. Pollut. Bull. 7 (5): 91-94

This paper was presented by Professor M. Anraku; it was accepted for printing on November 4, 1980 